\title{
Foraging dynamics of macaroni penguins Eudyptes chrysolophus at South Georgia during brood-guard
}

\author{
P. N. Trathan ${ }^{1, *}{ }^{,}$C. Green ${ }^{1}$, J. Tanton ${ }^{1}$, H. Peat ${ }^{1}$, J. Poncet $^{2}$, A. Morton ${ }^{1}$ \\ ${ }^{1}$ British Antarctic Survey, Natural Environment Research Council, High Cross, Madingley Road, Cambridge CB3 0ET, UK \\ ${ }^{2}$ Golden Fleece Expeditions, Beaver Island, Stanley, Falkland Islands FIQQ 1ES
}

\begin{abstract}
We used satellite telemetry methods to study macaroni penguins at South Georgia to determine how they ranged from their colonies during the early part of their breeding season at a time when they are constrained to return to their chicks on a near-daily basis. The principal objectives of this study were to examine whether these penguins exploit major oceanographic features where prey may be more predictable, whether birds from one colony forage in separate locations to those from nearby colonies, or whether they range evenly over the available area. Results show that the penguins did not range evenly, that birds from one colony tended to forage in locations separate from those used by birds from nearby colonies (or at least overlap was restricted), and that though birds from some colonies foraged within waters influenced by major oceanographic features such as the southern Antarctic Circumpolar Current front, not all birds in the region focused on such areas, as some birds foraged in other oceanographic contexts. The results from this study highlight the complexity of foraging dynamics for colonially nesting seabirds; they also help inform management models currently being developed for Antarctic krill fisheries, which are a potential competitor for the main prey of macaroni penguins.
\end{abstract}

KEY WORDS: Macaroni penguin · Foraging $\cdot$ Oceanography $\cdot$ Satellite telemetry $\cdot$ South Georgia Resale or republication not permitted without written consent of the publisher

\section{INTRODUCTION}

Whilst at sea, seabirds, particularly diving ones, are cryptic. They are generally difficult to observe and even more difficult to follow. Consequently, much of what is known about their life at sea derives from studies that explore their behaviour through the use of miniaturised electronic devices (Wilson et al. 2002). Such studies provide an image of the foraging track of seabirds, either through the use of time-depthrecorders to recreate their vertical dive profile (Cherel et al. 1999), or through the use of radio (Wanless et al. 1993) or satellite telemetry (Jouventin \& Weimerskirch 1990, Grémillet et al. 2004, Ryan et al. 2004) to recover a bird's horizontal route. Studies like these tell us a great deal about how seabirds make their living. However, most of them have been carried out from a relatively restricted set of sites, and as a consequence, still only little is known about the generality of recorded foraging patterns, or about how local context affects individuals from a specific colony. Thus, in spite of the many major technological advances in recent years, relating seabird foraging behaviour to the sea around them remains an underdeveloped area of seabird ecology.

For some species, particularly those for which a considerable archive of instrument data exists, post-hoc analyses in combination with more recent tracking data have the potential to offer fresh insights. One such species for which this is possible is the macaroni penguin Eudyptes chrysolophus. The species is one of the most abundant avian consumers of Antarctic krill Euphausia superba in the Southern Ocean (Croxall \& Prince 1987) and is therefore of considerable importance within the regional ecosystem. Current estimates suggest that in the seas around South Georgia, macaroni penguins consume approximately 8 million $\mathrm{t}$ of krill annually (Boyd 2002). In global terms, macaroni penguins are considered to be one of the more important avian marine predators, consuming more prey than any other 
seabird species (de le Brooke 2004). Thus, given the oceanographic context in which macaroni penguins forage, it is critically important to understand how their foraging decisions are influenced by local conditions in order to better understand the motivating factors governing their foraging behaviour.

Previous satellite telemetry studies describing the foraging locations of macaroni penguins are available (Barlow \& Croxall 2002, Barlow et al. 2002, Trathan \& Croxall 2004). They have so far only been conducted from Bird Island, a small offshore island near South Georgia. These studies indicate that macaroni penguins are very much constrained during the early stages of chick rearing, particularly during the broodguard period (Barlow \& Croxall 2002, Trathan \& Croxall 2004), when only females forage, with trips lasting on average about $12 \mathrm{~h}$ (Croxall et al. 1993). During brood-guard, males stay ashore and guard their chicks, which grow rapidly, increasing in weight by more than $1200 \mathrm{~g}$ (Williams 1995) over the course of the brood-guard period (approximately $20 \mathrm{~d}$ ). Female penguins tracked from Bird Island during brood-guard are very conservative in their foraging locations, travelling along a relatively restricted set of bearings (Barlow \& Croxall 2002, Trathan \& Croxall 2004). This is despite the fact that Bird Island is small and foraging could potentially occur over a much wider area. The reasons why macaroni penguins forage along such a restricted set of bearings are unknown, but it may be that penguins predominantly feed in areas that allow them to reduce competition from other land-based predators foraging from nearby colonies, whether penguins or fur seals (Barlow et al. 2002, Mori \& Boyd 2004, Trathan \& Croxall 2004). Alternatively, foraging behaviour could be linked to the local aggregation and persistence of prey in nutrient rich areas and/or to the flux of prey arriving in the regional ocean currents (Trathan et al. 1997, $2000,2003)$. If this is the case, then the proximity of major oceanographic features may be of greater importance to foraging penguins than the increased foraging area afforded by a small island situation. Knowledge of the factors governing their foraging distribution (e.g. local hydrography, prey distribution, resource competition etc.) at times when they are particularly constrained by the need to return to land to feed their chicks is fundamental to a wider understanding of their ecology, their interactions with other predator species and commercial fisheries.
The major oceanographic flows in the Scotia Sea follow the general direction of the Antarctic Circumpolar Current (ACC) (Fig. 1). The ACC contains a number of narrow, fast-moving frontal jets separated by broad, slower-moving zones of water. Close to South Georgia the fronts and the main flow of the ACC are topographically constrained by the bathymetry of the North Scotia Ridge; thus, the southern ACC front (sACCf) is steered anticyclonically around the continental shelf of the island (Orsi et al. 1995, Trathan et al. 1997, Thorpe et al. 2002). The sACCf has been implicated in the transport of krill across the Scotia Sea from the Antarctic Peninsula to South Georgia (Hofmann et al. 1998, Murphy et al. 1998, Trathan et al. 2003).

At South Georgia mesoscale oceanographic variability is known to be a key feature of the physical environment (Meredith et al. 2003, Trathan et al. 2003). The locations of the main fronts in the ACC are known to vary in the proximity of the island (Trathan et al. 2000, Thorpe et al. 2002) and are thought to be important in generating biological variability. The sACCf flows anticyclonically along the northern shelf edge at South Georgia (Orsi et al. 1995, Trathan et al. 1997, Thorpe et al. 2002), where it varies temporally and spatially, shedding eddies and influencing the environment within the potential foraging range of those colonies located on the northern coast. Recent modelling studies (Murphy et al. 2004) and oceanographic drifter studies (Meredith et al. 2003) have identified the regional importance of this flow. At South Georgia, macaroni penguin colonies are principally located

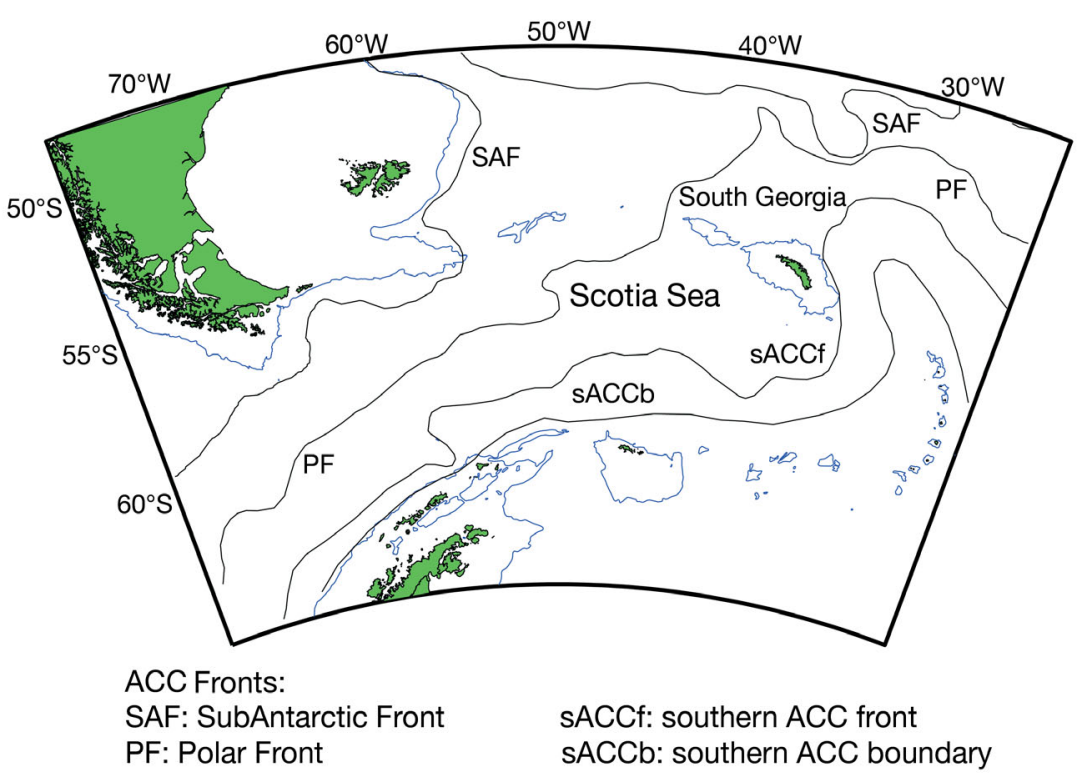

Fig. 1. Map of the south-west Atlantic showing the principal oceanographic features of the Antarctic Circumpolar Current (ACC): $1000 \mathrm{~m}$ isobath also shown 
along the north-western coast of the mainland and on a few of the smaller offshore islands (Fig. 2, see also Trathan et al. 1998). These locations provide ready access to the waters influenced by the sACCf.

The present study therefore sets out to use satellite telemetry to study macaroni penguins at South Georgia in order to determine how they range from different colonies during the early part of their breeding season at a time when they are most constrained by the need to return to land to feed their chicks. The principal objectives of the study (in priority order) were: (1) to determine whether penguins target specific oceanographic features where prey may be more predictable; (2) to establish whether individuals from 1 colony forage in locations separate from those of nearby colonies, and (3) to examine whether they forage along a restricted set of bearings, or whether they range evenly over the area available to them. Understanding the at-sea foraging behaviour of macaroni penguins is increasingly important given the potential changes to the ecosystem at South Georgia. Consequently, information about how penguins use the available seascape is important if we are to adequately predict the impacts of anthropogenic forcing (such as krill harvesting) and subsequent ecosystem response.

\section{MATERIALS AND METHODS}

The study was carried out at South Georgia in the south-west Atlantic. The breeding colonies used during our study are highlighted in Fig. 2. To test our hypotheses we carried out satellite telemetry studies at a number of sites located in contrasting locations:

- on a small island with direct access to waters influenced by the major oceanographic feature of the region (the $\mathrm{sACCf}$ ); in addition, this site also had a large potential foraging area;

- on a small island but with only indirect access to the same waters influenced by the same feature, though still with a large potential foraging area, and;

- on the mainland with direct access to the major oceanographic feature in the region, but with a more restricted potential foraging area.

Further, the colony locations were selected in order that we could access: colonies in very close proximity to each other and colonies that were more widely separated.

The first tracking site was at Bird Island where we used 3 colonies, Fairy Point $\left(54^{\circ} 0.42^{\prime} \mathrm{S}, 38^{\circ} 4.50^{\prime} \mathrm{W}\right)$, Goldcrest Point $\left(54^{\circ} 0.26^{\prime} \mathrm{S}, 38^{\circ} 4.50^{\prime} \mathrm{W}\right)$ and Macaroni Cwm (54 0.26' S, 38 1.62' W). Two colonies at Bird Island have been used for long-term monitoring studies over a

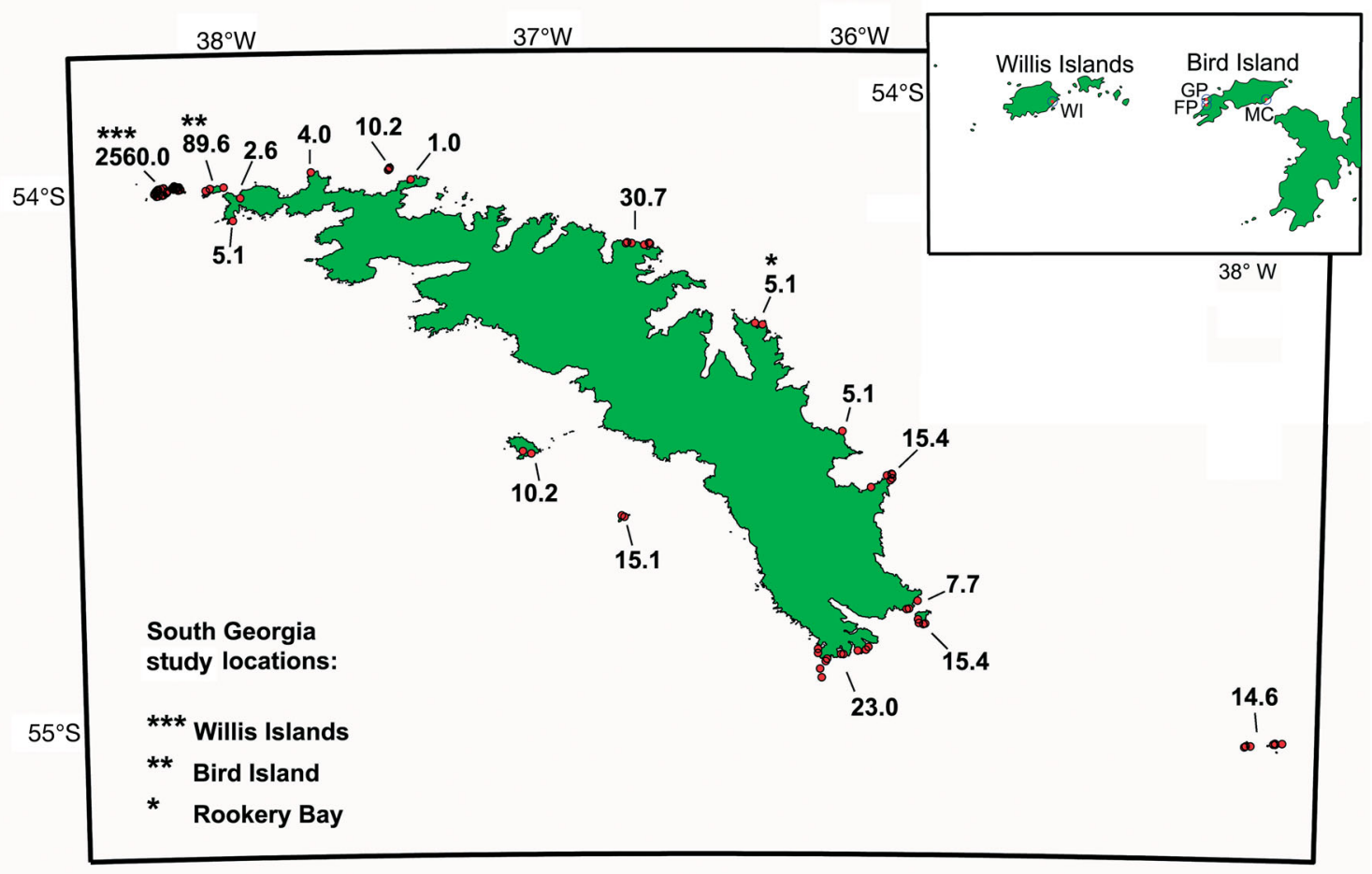

Fig. 2. Eudyptes chrysolophus. Macaroni penguin breeding aggregations at South Georgia. Location of aggregations and breeding population sizes (numbers in thousands) taken from Trathan et al. (1998); asterisks indicate our study locations. Inset shows a detailed map of the 3 study locations on Bird Island (FP: Fairy Point, GP: Goldcrest Point, MC: Macaroni Cwm) and the single study location on the Willis Islands (WI: Main Island) 
number of decades (Croxall et al. 1988, Trathan 2004), but only Fairy Point has been extensively used as the location of satellite telemetry studies. The second tracking site was at Main Island in the Willis Island archipelago situated at the westernmost tip of South Georgia. The Willis Islands are the main breeding centre for macaroni penguins at South Georgia. There are numerous colonies on the archipelago, and approximately $90 \%$ of the South Georgia population breeds there (Trathan et al. 1998). The colonies on the Willis Islands have a range of aspects and orientations (including all cardinal pointsof the compass); we selected 1 colony $\left(54^{\circ} 0.32^{\prime} \mathrm{S}\right.$, $38^{\circ} 11.94^{\prime} \mathrm{W}$ ) with a southerly aspect. The third tracking site was at Rookery Bay $\left(54^{\circ} 16.14^{\prime} \mathrm{S}, 36^{\circ} 19.20^{\prime} \mathrm{W}\right)$ on the central northern coast of South Georgia. Fieldwork was carried out over consecutive years between January 1999 and January 2005 (Table 1). Deployments were made at Bird Island every year. Deployments were made at Main Island and at Rookery Bay in January 2004.

ARGOS satellite-tracking instruments (Telonics ST10 devices [ $95 \times 42 \times 20 \mathrm{~mm}, 85 \mathrm{~g}]$, Kiwisat 101 $[130 \times 35 \times 20 \mathrm{~mm}, 100 \mathrm{~g}]$ and Wildlife Computers SPOT4 [90 $\times 20 \times 15 \mathrm{~mm}, 70 \mathrm{~g}])$ in a suitable package for penguins were deployed on breeding females foraging to feed their young. Instruments were, on average, less than $2.25 \%$ of mass and less than $2.75 \%$ of cross sectional area of the penguin. They were attached using established methodologies (modified after Wilson et al. 1997), previously well tested at Bird Island, i.e. using waterproof tape (Tesa AG) and quicksetting 2-part epoxy glue (RS Components). Birds were only selected when both partners were present at the nest and where the chick was at least a few days old. Only female birds were tracked as they undertake all foraging duties during brood-guard.

During the brood-guard period of January 2004 the duration of foraging trips was recorded at the Fairy Point study colony. Trips for female birds fitted with platform terminal transmitter (PTT) devices and with passive

Table 1. Eudyptes chrysolophus. Macaroni penguin schedule of satellite telemetry deployments

\begin{tabular}{|llrlrr|}
\hline Site & Colony & $\begin{array}{c}\text { Colony } \\
\text { pairs }\end{array}$ & Date & $\begin{array}{c}\text { Deploy- } \\
\text { ments }\end{array}$ & Trips \\
\hline Bird Island & Fairy Point & 537 & 2005, Jan 1-17 & 10 & 61 \\
Bird Island & Fairy Point & 463 & 2004, Jan 2-16 & 8 & 51 \\
Bird Island & Fairy Point & 536 & 2003, Jan 5-15 & 11 & 38 \\
Bird Island & Fairy Point & 513 & 2002, Jan 3-15 & 8 & 57 \\
Bird Island & Fairy Point & 475 & 2001, Jan 3-14 & 6 & 31 \\
Bird Island & Fairy Point & 497 & 2000, Jan 4-14 & 8 & 26 \\
Bird Island & Fairy Point & 579 & 1999, Jan 4-14 & 8 & 35 \\
Bird Island & Goldcrest Point & 43811 & 2003, Jan 2-15 & 8 & 42 \\
Bird Island & Macaroni Cwm & $\sim 10000$ & 2003, Jan 16-31 & 8 & 30 \\
Willis Islands Main Island & $\sim 10000$ & 2004, Jan 13-18 & 9 & 25 \\
Rookery Bay & East colony & $\sim 5000$ & 2004, Jan 7-13 & 10 & 27 \\
\hline
\end{tabular}

implantable transponder (PIT) tags were recorded, as were trips for control birds (identified only by PIT tags). For all birds, the time of departure and arrival was determined by an automatic PIT tag recognition gateway (Green et al. 2006). This was carried out in order to assess whether there were any discernible impacts of PTT devices on foraging trip duration.

Up-to-date ARGOS tracking information was relayed and accessed via the British Antarctic Survey (BAS) research station on Bird Island. This information was used to maximise instrument recovery. Instruments not recovered were considered unlikely to have any long-term effects on the bird's foraging ability, as the instrument package would be shed during the moult period at the end of the breeding season.

All data were loaded into Matlab (Mathworks), where they were subsequently manipulated and analysed. ARGOS location data of position Quality 3, Quality 2, Quality 1 and Quality 0 were accepted, data of position Quality A, Quality B, and Quality Z were rejected (for more details about quality and accuracy see cls.fr/html/argos/general/faq_en.html). For each foraging trip, the distance and speed between adjacent positions was calculated. Points were rejected if speeds exceeded $10 \mathrm{~km} \mathrm{~h}^{-1}$ (Barlow \& Croxall 2002, see also Clarke \& Bemis 1979, Brown 1987). For all accepted positions, the distance between the estimated location and the breeding colony and the distance between the location and the nearest point of land were calculated. Sinuosity for each trip was calculated as the ratio between the total distance travelled and the maximum distance travelled from the colony.

For each colony and for each year of the study, the foraging area used by penguins was represented by a minimum convex hull polygon (that is the smallest-area convex polygon that encloses all of the points); this was generated from a linear interpolation of the at-sea ARGOS locations, with the interpolation carried out on the basis of time (10 min intervals). The total area of each polygon was calculated (100\% area), as was the area occupied by the $90 \%$ use contour (90\% area).

\section{RESULTS}

At Bird Island, macaroni penguins breed in a highly synchronous manner (Williams \& Croxall 1991); temporal differences exist between colonies, but within a colony differences are usually relatively minor. Hatching takes place over a few days, usually at the end of December. At all other colonies on South Georgia peak hatching dates are 
unknown, but where examined, occur within a few days (10 to $14 \mathrm{~d}$ ) of those at Bird Island. Thus, some variability in the onset of brood-guard exists between the different colonies on South Georgia and the time when tracking could take place (Table 1).

All birds continued to successfully feed their chicks after the removal of the PTT devices; only 1 device was not successfully recovered (from Rookery Bay during January 2004).

\section{Satellite telemetry}

Comparison between birds fitted with PTT devices and controls

In January 2004 the average trip duration for broodguard foraging trips was recorded for birds fitted with PTT devices and for control birds (identified with PIT tags). Our study birds comprised 8 birds with 51 trips and our control birds comprised 24 birds and 156 trips. The data showed that penguins fitted with PTT devices started their foraging trips earlier in the day (average trip start time for PTT birds was at 07:25 h, standard deviation of $\pm 07: 44$; average trip start time for control birds was at 08:59 h, standard deviation of $\pm 04: 33$; Student's $t$-test $=$ 1.75, df $=205, \mathrm{p}>0.05$ ) and that foraging trips were shorter in duration (average trip duration for PTT birds was 11:27 $\mathrm{h}$, standard deviation of \pm 9 :08; average trip duration for control birds was 11:34 h, standard deviation of $\pm 16: 15 ; t=5.32$, df $=205, \mathrm{p}<0.01$ ). Furthermore, the proportion of trips that continued overnight into a second or subsequent day of foraging was lower for study birds $(\sim 18 \%, 9$ out of 51$)$ than for control birds $(\sim 40 \%, 62$ out of 156$)$.

\section{Comparison between birds from same colony in different years}

Foraging trip descriptors derived from PTT data from birds breeding at Fairy Point are shown in Table 2; these data describe the brood-guard period of consecutive breeding seasons (January 1999 through January 2005). The data suggest that brood-guard foraging trips varied considerably between years; the time at sea $\left(\right.$ ANOVA, $\left.F_{6,292}=7.4, \mathrm{p}<0.01\right)$, the total distance travelled (ANOVA, $\left.F_{6,292}=8.4, \mathrm{p}<0.01\right)$, the maximum distance travelled from the colony (ANOVA, $F_{6,292}=23.5, \mathrm{p}<0.01$ ), and the sinuosity (ANOVA, $\left.F_{6,292}=3.9, \mathrm{p}<0.01\right)$ all showed significant variation between years. No differences between uplink rate (uplinks h${ }^{-1}$ ) were evident (ANOVA, $F_{6,292}=0.5, \mathrm{p}>$ 0.05), and no relationship between uplink rate and sinuosity was evident (correlation $\mathrm{R}^{2}=0.05, F_{1,297}=0.7$, $\mathrm{p}>0.05)$.

Each year the foraging area used by penguins differed, represented by the minimum convex hull polygons. As with all similar range studies (Barlow \& Croxall 2002), our data showed that the outer (100\%) polygon was of greater area than the core area used by our study birds. An indication of where the maximum time spent foraging was located is given by the maximum value from the interpolated polygon surface (Fig. 3; in Table 3 the arithmetic mean of the actual ARGOS locations is also given for comparison). A broader indication of where foraging took place is given by the area encompassed within the $90 \%$ contour taken from the interpolated surface (Table 4). The degree of overlap between years for core areas $(90 \%$ contour) highlights the restricted area used in the majority of years.

Table 2. Eudyptes chrysolophus. Macaroni penguin number of uplinks per trip, cumulative time per trip, cumulative distance travelled per trip, maximum distance travelled from the colony and sinuosity per trip. Data (value \pm standard deviation) are from birds fitted with platform terminal transmitter (PTT) devices at different colonies. FP: Fairy Point, Bird Island; GP: Goldcrest Point, Bird Island; MC: Macaroni Cwm, Bird Island; WI: Main Island, Willis Islands; RB: Rookery Bay, South Georgia

\begin{tabular}{|lccccccc|}
\hline Colony & Year & $\begin{array}{c}\text { No. of } \\
\text { trips }\end{array}$ & $\begin{array}{c}\text { No. of uplinks } \\
\text { per trip }\end{array}$ & $\begin{array}{c}\text { Total time } \\
\text { at sea }(\mathrm{h})\end{array}$ & $\begin{array}{c}\text { Total distance } \\
\text { travelled }(\mathrm{km})\end{array}$ & $\begin{array}{c}\text { Maximum distance } \\
\text { from colony (km) }\end{array}$ & $\begin{array}{c}\text { Sinuosity } \\
\text { FP }\end{array}$ \\
\hline FP & 2005 & 61 & $15.9 \pm 15.6$ & $13.2 \pm 13.9$ & $101.2 \pm 104.1$ & $39.1 \pm 23.6$ & $1.557 \pm 0.82$ \\
FP & 2004 & 51 & $10.3 \pm 6.4$ & $11.5 \pm 9.2$ & $95.8 \pm 41.7$ & $69.4 \pm 33.4$ & $1.091 \pm 0.11$ \\
FP & 2002 & 38 & $18.0 \pm 15.7$ & $17.9 \pm 16.4$ & $114.2 \pm 134.1$ & $37.8 \pm 29.9$ & $1.670 \pm 0.62$ \\
FP & 2001 & 31 & $6.9 \pm 8.2$ & $9.1 \pm 9.9$ & $47.3 \pm 40.9$ & $26.6 \pm 17.8$ & $1.232 \pm 0.42$ \\
FP & 2000 & 26 & $4.8 \pm 1.8$ & $9.1 \pm 8.1$ & $39.3 \pm 27.7$ & $18.0 \pm 9.2$ & $1.283 \pm 0.43$ \\
FP & 1999 & 35 & $17.8 \pm 40.0$ & $23.8 \pm 15.6$ & $155.5 \pm 102.0$ & $59.9 \pm 2.5$ & $1.703 \pm 0.92$ \\
GP & 2003 & 42 & $21.0 \pm 17.7$ & $21.3 \pm 15.2$ & $162.6 \pm 131.3$ & $47.3 \pm 23.1$ & $1.531 \pm 0.72$ \\
MC & 2003 & 30 & $12.0 \pm 10.8$ & $15.2 \pm 12.3$ & $61.6 \pm 55.9$ & $29.9 \pm 23.6$ & $1.685 \pm 0.63$ \\
WI & 2004 & 25 & $15.4 \pm 12.5$ & $13.8 \pm 11.7$ & $91.7 \pm 72.9$ & $40.8 \pm 29.9$ & $1.575 \pm 0.71$ \\
RB & 2004 & 27 & $9.3 \pm 6.3$ & $9.8 \pm 8.8$ & $59.3 \pm 42.0$ & $31.9 \pm 22.8$ & $1.217 \pm 0.34$ \\
\hline
\end{tabular}




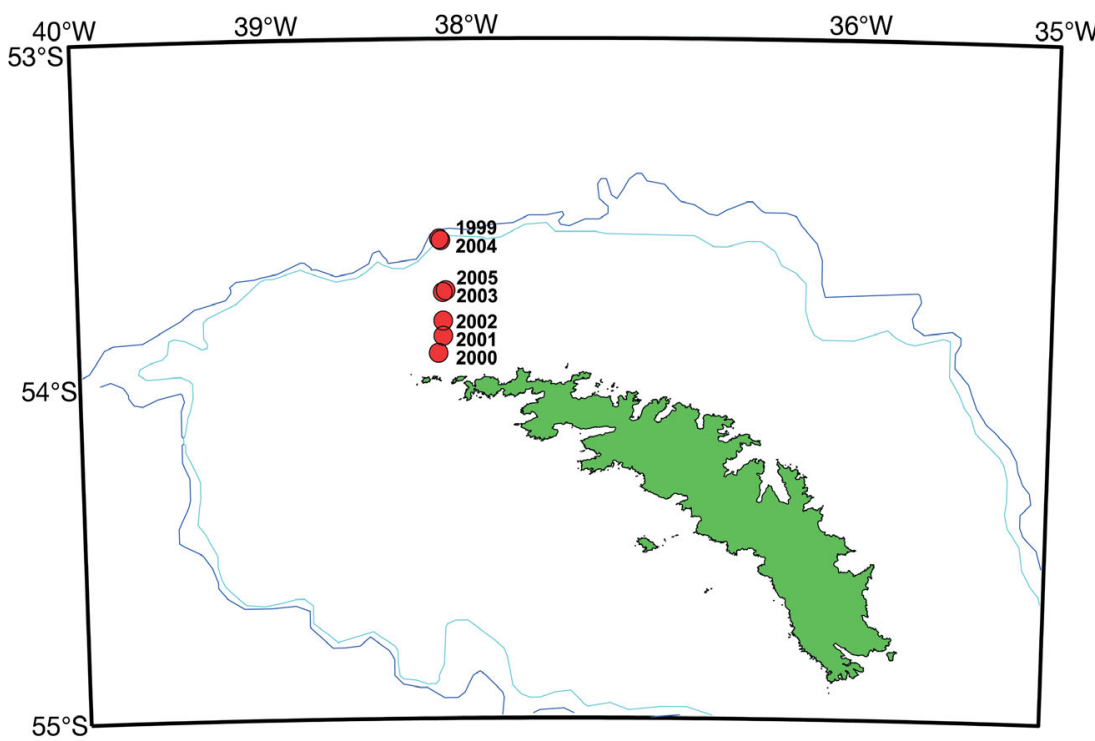

Fig. 3. Eudyptes chrysolophus. Macaroni penguin foraging polygons (interpolated at 10 min intervals); maximum value locations for birds from Fairy Point recorded from brood-guard trips over consecutive years between 1999 and 2005

Comparison between birds from closely adjacent colonies in the same year

The minimum convex hull foraging polygons for birds from 3 closely adjacent colonies (Fairy Point, Goldcrest Point and Macaroni Cwm) during January 2003 are shown in Fig. 4. The $90 \%$ polygons derived from these foraging polygons are shown in Fig. 5a and the foraging trip descriptors describing the individual trips are given in Table 2 . The data indicate that brood-guard foraging trips varied between colonies; the time at sea (ANOVA, $\left.F_{2,107}=1.0, \mathrm{p}>0.05\right)$ and the maximum distance travelled from the colony (ANOVA, $F_{2,107}=1.8, \mathrm{p}>0.05$ ) were not significantly different; however, the total distance travelled (ANOVA, $F_{2,107}=3.4, \mathrm{p}<0.05$ ), and the sinuosity (ANOVA, $F_{2,107}=4.6, \mathrm{p}<0.01$ ) both varied. A significant difference in uplink rate was evident (ANOVA, $F_{2,107}$ $=6.3, \mathrm{p}<0.01$ ), though there was no relationship between uplink rate and sinuosity (correlation $\mathrm{R}^{2}=0.05, F_{1,108}=0.2$, $\mathrm{p}>0.05)$.

An indication of where the maximum time spent foraging was located is given by the maximum value from the interpolated polygon surface (Table 3). A broader indication of where foraging took place is given by the area encompassed within the $90 \%$ contour taken from the polygon surface (Table 5). The degree of overlap between core areas (90\% contour) varied, and highlighted the separation between these closely adjacent colonies.

The $90 \%$ foraging polygons derived from PTT data from birds from 3 more widely spaced colonies (Fairy Point, Willis Islands and Rookery Bay) during the brood-guard period of January 2004 are shown in Fig. 5b. These polygons indicated that the degree of overlap between core areas (90\% contour) was negligible (Table 5), highlighting the greater separation between these more widely separated colonies. The foraging trip descriptors describing these trips are given in Table 2. These data suggest that at this larger scale, brood-guard foraging trips again varied between colonies; though the time at sea (ANOVA, $F_{2,100}=1.0, \mathrm{p}>0.05$ ) did not differ, the total distance

Table 3. Eudyptes chrysolophus. Macaroni penguin foraging polygons (interpolated at 10 min intervals). Data (value \pm standard deviation) are from birds fitted with PTT devices at different colonies. FP: Fairy Point, Bird Island; GP: Goldcrest Point, Bird Island; MC: Macaroni Cwm, Bird Island; WI: Main Island, Willis Islands; RB: Rookery Bay, South Georgia

\begin{tabular}{|c|c|c|c|c|c|c|}
\hline Colony & Year & $\begin{array}{c}\text { Mean latitude } \\
\text { of ARGOS } \\
\text { locations }\end{array}$ & $\begin{array}{c}\text { Mean longitude } \\
\text { of ARGOS } \\
\text { locations }\end{array}$ & $\begin{array}{c}\text { Latitude of } \\
\text { maximum } \\
\text { accumulated time }\end{array}$ & $\begin{array}{c}\text { Longitude of } \\
\text { maximum } \\
\text { accumulated time }\end{array}$ & $\begin{array}{l}\text { Area of foraging } \\
\text { polygon }\left(\mathrm{km}^{2}\right)\end{array}$ \\
\hline FP & 2005 & $-53.722 \pm 0.24$ & $-38.079 \pm 0.20$ & -53.741 & -38.112 & 11206 \\
\hline FP & 2004 & $-53.465 \pm 0.33$ & $-38.207 \pm 0.30$ & -53.593 & -38.136 & 9340 \\
\hline FP & 2003 & $-53.708 \pm 0.25$ & $-38.119 \pm 0.18$ & -53.746 & -38.126 & 8228 \\
\hline FP & 2002 & $-53.771 \pm 0.20$ & $-38.171 \pm 0.23$ & -53.830 & -38.125 & 3895 \\
\hline FP & 2001 & $-53.948 \pm 0.08$ & $-38.079 \pm 0.12$ & -53.875 & -38.125 & 1597 \\
\hline FP & 2000 & $-53.963 \pm 0.08$ & $-38.085 \pm 0.12$ & -53.925 & -38.150 & 709 \\
\hline FP & 1999 & $-53.600 \pm 0.21$ & $-38.161 \pm 0.19$ & -53.589 & -38.143 & 5919 \\
\hline GP & 2003 & $-53.713 \pm 0.25$ & $-38.195 \pm 0.27$ & -53.850 & -38.142 & 10663 \\
\hline $\mathrm{MC}$ & 2003 & $-53.807 \pm 0.22$ & $-37.800 \pm 0.25$ & -53.850 & -37.850 & 4806 \\
\hline WI & 2004 & $-54.124 \pm 0.37$ & $-38.362 \pm 0.22$ & -54.360 & -38.360 & 8381 \\
\hline $\mathrm{RB}$ & 2004 & $-54.082 \pm 0.17$ & $-35.975 \pm 0.25$ & -54.125 & -36.350 & 4944 \\
\hline
\end{tabular}


Table 4. Eudyptes chrysolophus. Macaroni penguin foraging polygon (interpolated at 10 min intervals) overlap in area between different years $\left(\mathrm{km}^{2}\right): 100 \%$ area is the overlap in the total area used; $90 \%$ area is the overlap in the area enclosed by the $90 \%$ contour; percentage overlap is also given (\%). Grey boxes along main diagonal indicate actual polygon area values for individual years. Data are from birds fitted with PTT devices at Fairy Point (FP)

\begin{tabular}{|c|c|c|c|c|c|c|c|c|c|c|c|c|c|c|}
\hline \multirow[t]{2}{*}{ FP } & \multicolumn{2}{|c|}{$-1999-$} & \multicolumn{2}{|c|}{-2000} & \multicolumn{2}{|c|}{$-2001-$} & \multicolumn{2}{|c|}{-2002} & \multicolumn{2}{|c|}{-2003} & \multicolumn{2}{|c|}{$-2004-$} & \multicolumn{2}{|c|}{$-2005-$} \\
\hline & $\begin{array}{l}90 \% \\
\text { area }\end{array}$ & $\begin{array}{c}100 \% \\
\text { area }\end{array}$ & $\begin{array}{l}90 \% \\
\text { area }\end{array}$ & $\begin{array}{c}100 \% \\
\text { area }\end{array}$ & $\begin{array}{l}90 \% \\
\text { area }\end{array}$ & $\begin{array}{c}100 \% \\
\text { area }\end{array}$ & $\begin{array}{l}90 \% \\
\text { area }\end{array}$ & $\begin{array}{c}100 \% \\
\text { area }\end{array}$ & $\begin{array}{l}90 \% \\
\text { area }\end{array}$ & $\begin{array}{c}100 \% \\
\text { area }\end{array}$ & $\begin{array}{l}90 \% \\
\text { area }\end{array}$ & $\begin{array}{c}100 \% \\
\text { area }\end{array}$ & $\begin{array}{l}90 \% \\
\text { area }\end{array}$ & $\begin{array}{c}100 \% \\
\text { area }\end{array}$ \\
\hline $\begin{array}{c}1999\left(\mathrm{~km}^{2}\right) \\
(\%)\end{array}$ & $\begin{array}{l}585.2 \\
100.0\end{array}$ & $\begin{array}{c}5918.8 \\
100.0\end{array}$ & & & & & & & & & & & & \\
\hline $\begin{array}{c}2000\left(\mathrm{~km}^{2}\right) \\
(\%)\end{array}$ & $\begin{array}{l}0.0 \\
0.0\end{array}$ & $\begin{array}{c}532.3 \\
9.0\end{array}$ & $\begin{array}{c}70.9 \\
100.0\end{array}$ & $\begin{array}{l}709.0 \\
100.0\end{array}$ & & & & & & & & & & \\
\hline $\begin{array}{c}2001\left(\mathrm{~km}^{2}\right) \\
(\%)\end{array}$ & $\begin{array}{l}0.0 \\
0.0\end{array}$ & $\begin{array}{c}1349.8 \\
22.8\end{array}$ & $\begin{array}{c}70.9 \\
100.0\end{array}$ & $\begin{array}{l}709.0 \\
100.0\end{array}$ & $\begin{array}{l}159.7 \\
100.0\end{array}$ & $\begin{array}{c}1597.7 \\
100.0\end{array}$ & & & & & & & & \\
\hline $\begin{array}{c}2002\left(\mathrm{~km}^{2}\right) \\
(\%)\end{array}$ & $\begin{array}{c}124.2 \\
21.2\end{array}$ & $\begin{array}{c}3278.9 \\
55.4\end{array}$ & $\begin{array}{c}70.9 \\
100.0\end{array}$ & $\begin{array}{l}709.0 \\
100.0\end{array}$ & $\begin{array}{l}159.7 \\
100.0\end{array}$ & $\begin{array}{c}1490.8 \\
93.3\end{array}$ & $\begin{array}{l}390.4 \\
100.0\end{array}$ & $\begin{array}{c}3895.1 \\
100.0\end{array}$ & & & & & & \\
\hline $\begin{array}{c}2003\left(\mathrm{~km}^{2}\right) \\
(\%)\end{array}$ & $\begin{array}{c}425.6 \\
72.7\end{array}$ & $\begin{array}{c}5145.7 \\
86.9\end{array}$ & $\begin{array}{c}70.9 \\
100.0\end{array}$ & $\begin{array}{l}709.0 \\
100.0\end{array}$ & $\begin{array}{l}159.7 \\
100.0\end{array}$ & $\begin{array}{c}1597.7 \\
100.0\end{array}$ & $\begin{array}{l}390.4 \\
100.0\end{array}$ & $\begin{array}{c}3805.4 \\
97.7\end{array}$ & $\begin{array}{l}816.3 \\
100.0\end{array}$ & $\begin{array}{c}8228.5 \\
100.0\end{array}$ & & & & \\
\hline $\begin{array}{c}2004\left(\mathrm{~km}^{2}\right) \\
(\%)\end{array}$ & $\begin{array}{l}585.2 \\
100.0\end{array}$ & $\begin{array}{c}5253.2 \\
88.8\end{array}$ & $\begin{array}{l}0.0 \\
0.0\end{array}$ & $\begin{array}{c}691.3 \\
97.5\end{array}$ & $\begin{array}{l}35.5 \\
22.2\end{array}$ & $\begin{array}{c}1580.1 \\
98.9\end{array}$ & $\begin{array}{c}213.0 \\
54.6\end{array}$ & $\begin{array}{c}3577.9 \\
91.9\end{array}$ & $\begin{array}{c}567.7 \\
69.5\end{array}$ & $\begin{array}{c}6456.4 \\
78.5\end{array}$ & $\begin{array}{l}940.1 \\
100.0\end{array}$ & $\begin{array}{c}9340.1 \\
100.0\end{array}$ & & \\
\hline $\begin{array}{c}2005\left(\mathrm{~km}^{2}\right) \\
(\%)\end{array}$ & $\begin{array}{c}372.5 \\
63.7\end{array}$ & $\begin{array}{c}5702.6 \\
96.4\end{array}$ & $\begin{array}{c}70.9 \\
100.0\end{array}$ & $\begin{array}{l}709.0 \\
100.0\end{array}$ & $\begin{array}{l}159.7 \\
100.0\end{array}$ & $\begin{array}{c}1597.7 \\
100.0\end{array}$ & $\begin{array}{l}390.4 \\
100.0\end{array}$ & $\begin{array}{c}3895.1 \\
100.0\end{array}$ & $\begin{array}{c}763.2 \\
93.5\end{array}$ & $\begin{array}{c}7960.6 \\
96.7\end{array}$ & $\begin{array}{c}550.1 \\
58.5\end{array}$ & $\begin{array}{c}6752.0 \\
72.3\end{array}$ & $\begin{array}{c}1118.2 \\
100.0\end{array}$ & $\begin{array}{c}11206.0 \\
100.0\end{array}$ \\
\hline
\end{tabular}

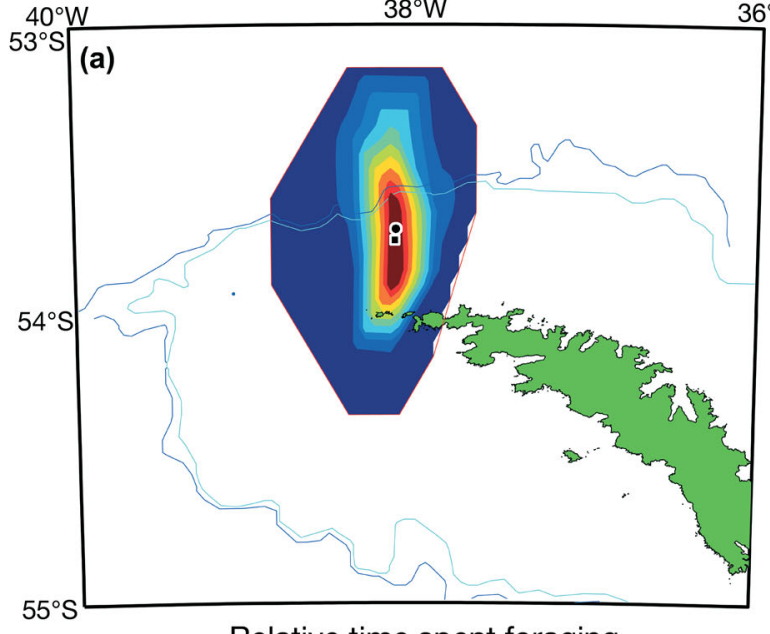

Relative time spent foraging

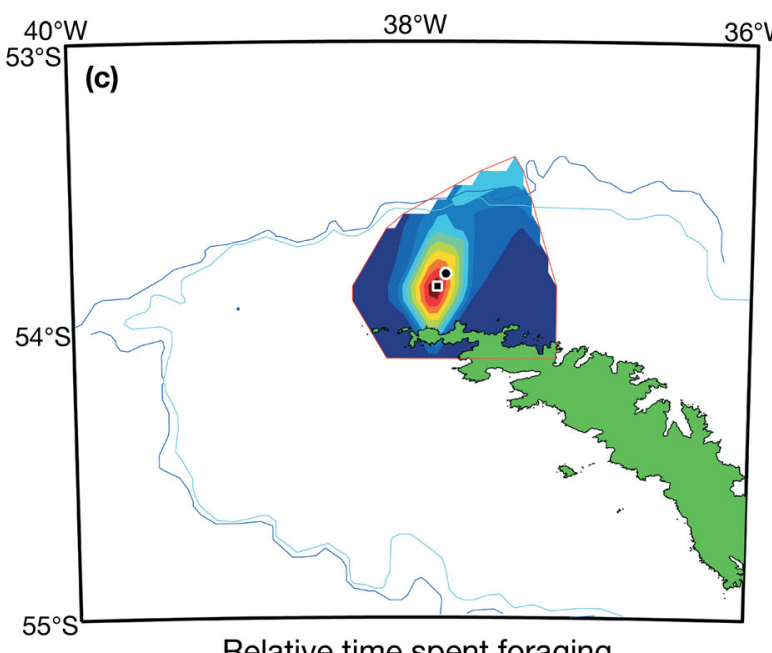

Relative time spent foraging

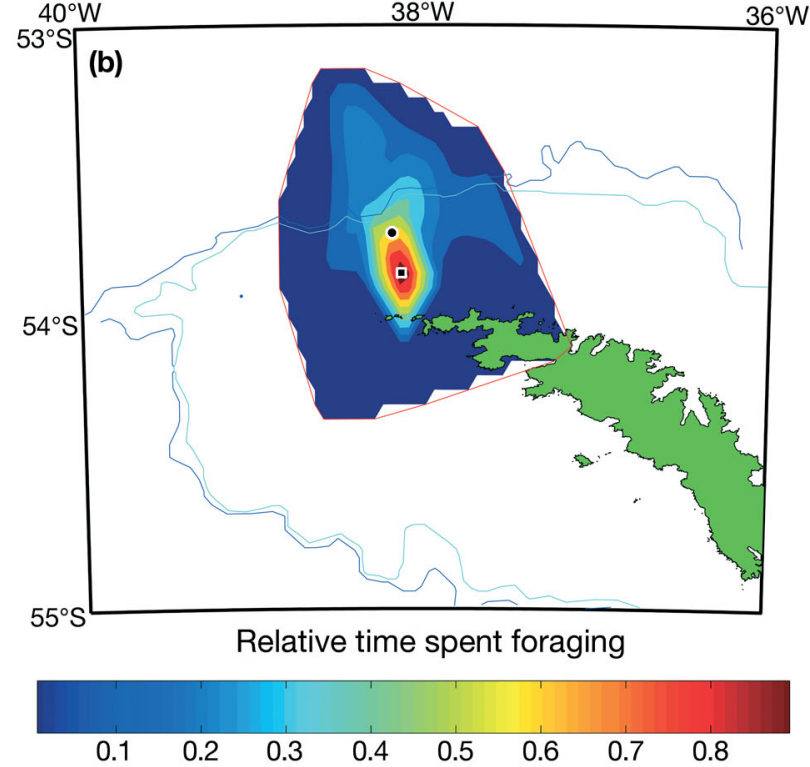

Fig. 4. Eudyptes chrysolophus. Macaroni penguin 100\% foraging polygons (interpolated at 10 min intervals) showing relative use during January 2003; polygon limits indicated by thin red line. (匹) Location of the maximum accumulated time; (•) mean location of the ARGOS positions. Data are from ARGOS satellite telemetry of breeding females from 3 colonies on Bird Island: (a) Fairy Point; (b) Goldcrest Point; and; (c) Macaroni Cwm 

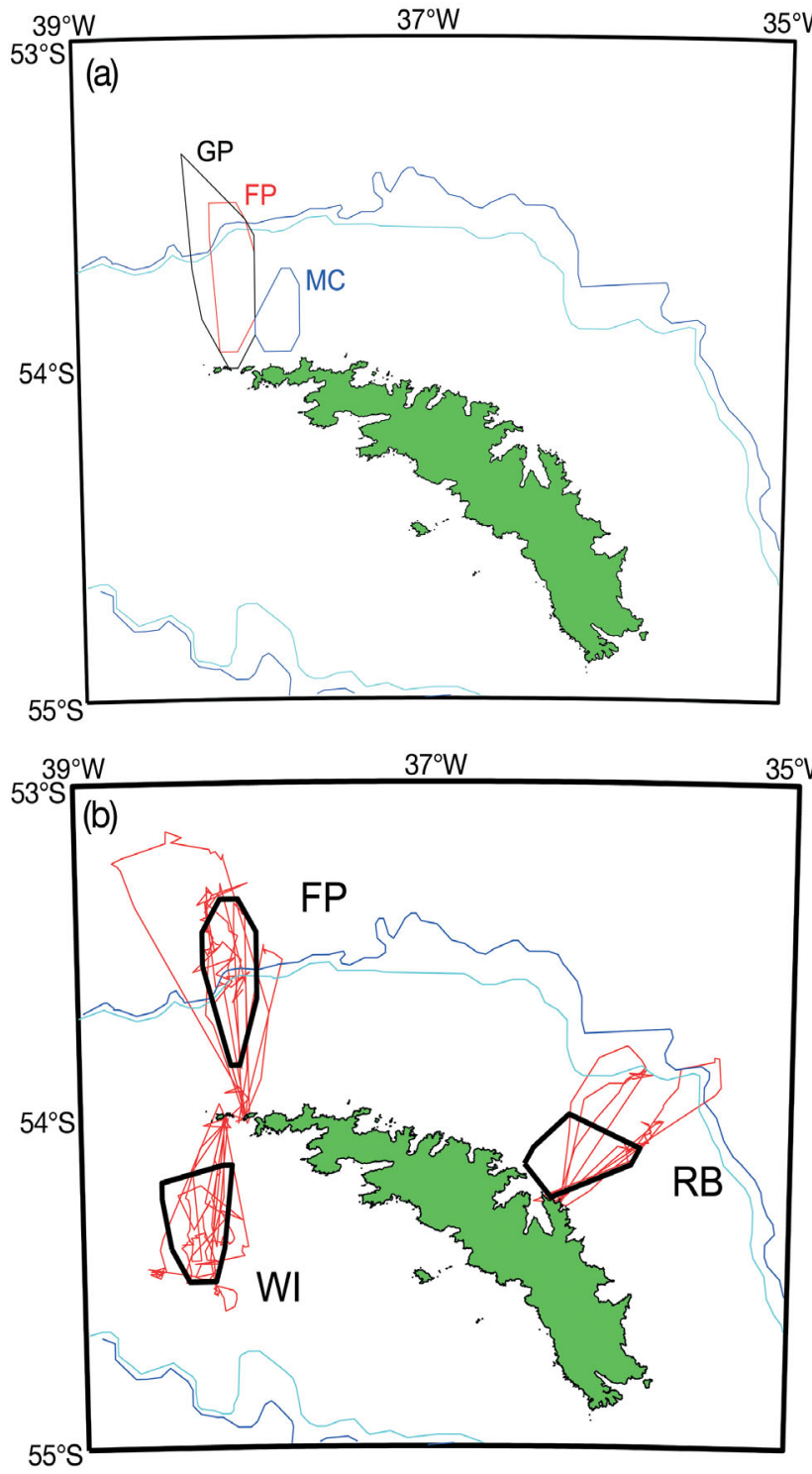

Fig. 5. Eudyptes chrysolophus. Macaroni penguin $90 \%$ foraging polygons (interpolated at $10 \mathrm{~min}$ intervals). Data are from ARGOS satellite telemetry of breeding females from (a) 3 colonies on Bird Island during 2003 (FP: Fairy Point: GP: Goldcrest Point: MC: Macaroni Cwm) or (b) 3 colonies on South Georgia during 2004 (FP: Fairy Point; WI: Willis Islands; RB: Rookery Bay). Example tracks from satellite telemetry of individual penguins (red lines) also shown

travelled (ANOVA, $F_{2,100}=6.2, \mathrm{p}<0.01$ ), the maximum distance travelled from the colony (ANOVA, $F_{2,100}=20.4, \mathrm{p}<0.01$ ) and the sinuosity (ANOVA, $\left.F_{2,100}=10.5, \mathrm{p}<0.01\right)$ all varied. No differences between uplink rate were evident (ANOVA, $F_{2,100}=$ $0.6, \mathrm{p}>0.05)$, and no relationship between uplink rate and sinuosity was evident (correlation $\mathrm{R}^{2}=0.05$, $\left.F_{1,101}=0.2, \mathrm{p}>0.05\right)$.
Comparison between number of foraging trips and polygon area

It is plausible that the location of foraging could vary with individual behavioural preferences of different birds and this could potentially alter the size and location of the polygon. However, in our study the area of the foraging polygon and the number of foraging trips showed no significant relationship. (All colonies, all years: correlation $\mathrm{R}^{2}=0.25, F_{1,9}=3.02, \mathrm{p}>0.05$. Fairy Point, all years: correlation $\mathrm{R}^{2}=0.47, F_{1,5}=$ $4.50, \mathrm{p}>0.05)$.

\section{Environmental data}

The tracks of ARGOS satellite telemetry drifting buoys during the brood-guard period of 2002 taken from Meredith et al. (2003) show the movement of water close to South Georgia (see also Korb \& Whitehouse 2004) in the foraging area used by penguins (Fig. 6). The image particularly highlights the presence of small to mesoscale oceanographic structure over the shelf where some of the drifting buoys were retained for short periods; it also shows the flow of water along the shelf edge and the flow around the steep bathymetry of the North Georgia Rise (Meredith et al. 2003).

\section{DISCUSSION}

It was not possible to determine whether the foraging location of our study birds differed from those of appropriate control birds. However, our results did show that the duration of foraging trips for instrumented birds were slightly different than those of controls. Even though some of these differences were statistically significant, we nevertheless believe that the biological significance was marginal and not of sufficient magnitude so as to compromise our study birds, their chicks, or the satellite tracking results. Additional evidence supporting this view comes from the level of variability evident between years in the average duration of foraging trips recorded at Fairy Point (Table 2); these inter-annual differences greatly exceeded the small differences recorded between our study birds and our control birds during 2004. We therefore believe that our tracking results adequately represent the foraging behaviour of individuals from their respective colonies.

The different locations of our study colonies allowed us to consider foraging behaviour in different geographic and oceanographic scenarios; we therefore discuss some of these in the following sections. 
Table 5. Eudyptes chrysolophus. Macaroni penguin foraging polygon (interpolated at 10 min intervals) overlap in area between separate colonies in the same year $\left(\mathrm{km}^{2}\right): 100 \%$ area is the overlap in the total area used; $90 \%$ area is the overlap in the area enclosed by the $90 \%$ contour; percentage overlap is also given (\%). Grey boxes along main diagonal indicate actual polygon area values for individual colonies. Data are from birds fitted with PTT devices at FP: Fairy Point, Bird Island; GP: Goldcrest Point, Bird Island; MC: Macaroni Cwm, Bird Island; WI: Main Island, Willis Islands; RB: Rookery Bay, South Georgia

\begin{tabular}{|c|c|c|c|c|c|c|}
\hline \multirow[t]{2}{*}{2003} & \multicolumn{2}{|c|}{$\longrightarrow$ FP } & \multicolumn{2}{|c|}{$-\mathrm{GP}=$} & \multicolumn{2}{|c|}{$\mathrm{MC}$} \\
\hline & $\begin{array}{l}90 \% \\
\text { area }\end{array}$ & $\begin{array}{c}100 \% \\
\text { area }\end{array}$ & $\begin{array}{l}90 \% \\
\text { area }\end{array}$ & $\begin{array}{c}100 \% \\
\text { area }\end{array}$ & $\begin{array}{l}90 \% \\
\text { area }\end{array}$ & $\begin{array}{c}100 \% \\
\text { area }\end{array}$ \\
\hline $\begin{array}{c}\mathrm{FP}\left(\mathrm{km}^{2}\right) \\
(\%)\end{array}$ & $\begin{array}{l}816.3 \\
100.0\end{array}$ & $\begin{array}{r}8228.5 \\
100.0\end{array}$ & & & & \\
\hline $\begin{array}{c}\mathrm{GP}\left(\mathrm{km}^{2}\right) \\
(\%)\end{array}$ & $\begin{array}{r}692.1 \\
84.8\end{array}$ & $\begin{array}{r}7676.4 \\
93.3\end{array}$ & $\begin{array}{r}1063.7 \\
100.0\end{array}$ & $\begin{array}{r}10663.0 \\
100.0\end{array}$ & & \\
\hline $\begin{array}{c}\mathrm{MC}\left(\mathrm{km}^{2}\right) \\
(\%)\end{array}$ & $\begin{array}{r}17.8 \\
2.2\end{array}$ & $\begin{array}{r}2172.5 \\
26.4\end{array}$ & $\begin{array}{r}35.6 \\
3.4\end{array}$ & $\begin{array}{r}3973.4 \\
37.3\end{array}$ & $\begin{array}{l}482.3 \\
100.0\end{array}$ & $\begin{array}{r}4805.9 \\
100.0\end{array}$ \\
\hline \multirow[t]{2}{*}{2004} & \multicolumn{2}{|c|}{$-\mathrm{FP}$} & \multicolumn{2}{|c|}{$-\mathrm{RB}=$} & \multicolumn{2}{|c|}{$-\mathrm{WI}$} \\
\hline & $\begin{array}{l}90 \% \\
\text { area }\end{array}$ & $\begin{array}{c}100 \% \\
\text { area }\end{array}$ & $\begin{array}{l}90 \% \\
\text { area }\end{array}$ & $\begin{array}{c}100 \% \\
\text { area }\end{array}$ & $\begin{array}{l}90 \% \\
\text { area }\end{array}$ & $\begin{array}{c}100 \% \\
\text { area }\end{array}$ \\
\hline $\begin{array}{c}\mathrm{FP}\left(\mathrm{km}^{2}\right) \\
(\%)\end{array}$ & $\begin{array}{l}940.1 \\
100.0\end{array}$ & $\begin{array}{r}9340.1 \\
100.0\end{array}$ & & & & \\
\hline $\begin{array}{c}\mathrm{GP}\left(\mathrm{km}^{2}\right) \\
(\%)\end{array}$ & $\begin{array}{l}0.0 \\
0.0\end{array}$ & $\begin{array}{l}0.0 \\
0.0\end{array}$ & $\begin{array}{l}482.5 \\
100.0\end{array}$ & $\begin{array}{r}4943.7 \\
100.0\end{array}$ & & \\
\hline $\begin{array}{c}\mathrm{MC}\left(\mathrm{km}^{2}\right) \\
(\%)\end{array}$ & $\begin{array}{l}0.0 \\
0.0\end{array}$ & $\begin{array}{r}4586.5 \\
55.7\end{array}$ & $\begin{array}{l}0.0 \\
0.0\end{array}$ & $\begin{array}{l}0.0 \\
0.0\end{array}$ & $\begin{array}{l}847.0 \\
100.0\end{array}$ & $\begin{array}{r}8380.7 \\
100.0\end{array}$ \\
\hline
\end{tabular}

\section{Comparison between birds from same colony in different years}

The Fairy Point colony was tracked during the brood-guard period of 7 consecutive seasons. Each season the birds foraged over the northern shelf of South Georgia. In different years birds from Fairy Point had similar trajectories and generally foraged directly towards the shelf break. In each year, the locations where the maximum accumulated time spent foraging (maximum accumulated time latitude and longitude, Table 3) were similar, with the locations falling along a vector heading directly towards the shelf break (Fig. 3). This would suggest that birds foraged in a predictable and consistent manner in every year. During brood-guard, birds are particularly constrained and must return to feed their chicks at regular and frequent intervals. Birds must therefore locate adequate patches of prey rapidly and within the short time available before their chick begins to starve. That the mean positions for the annual foraging poly-

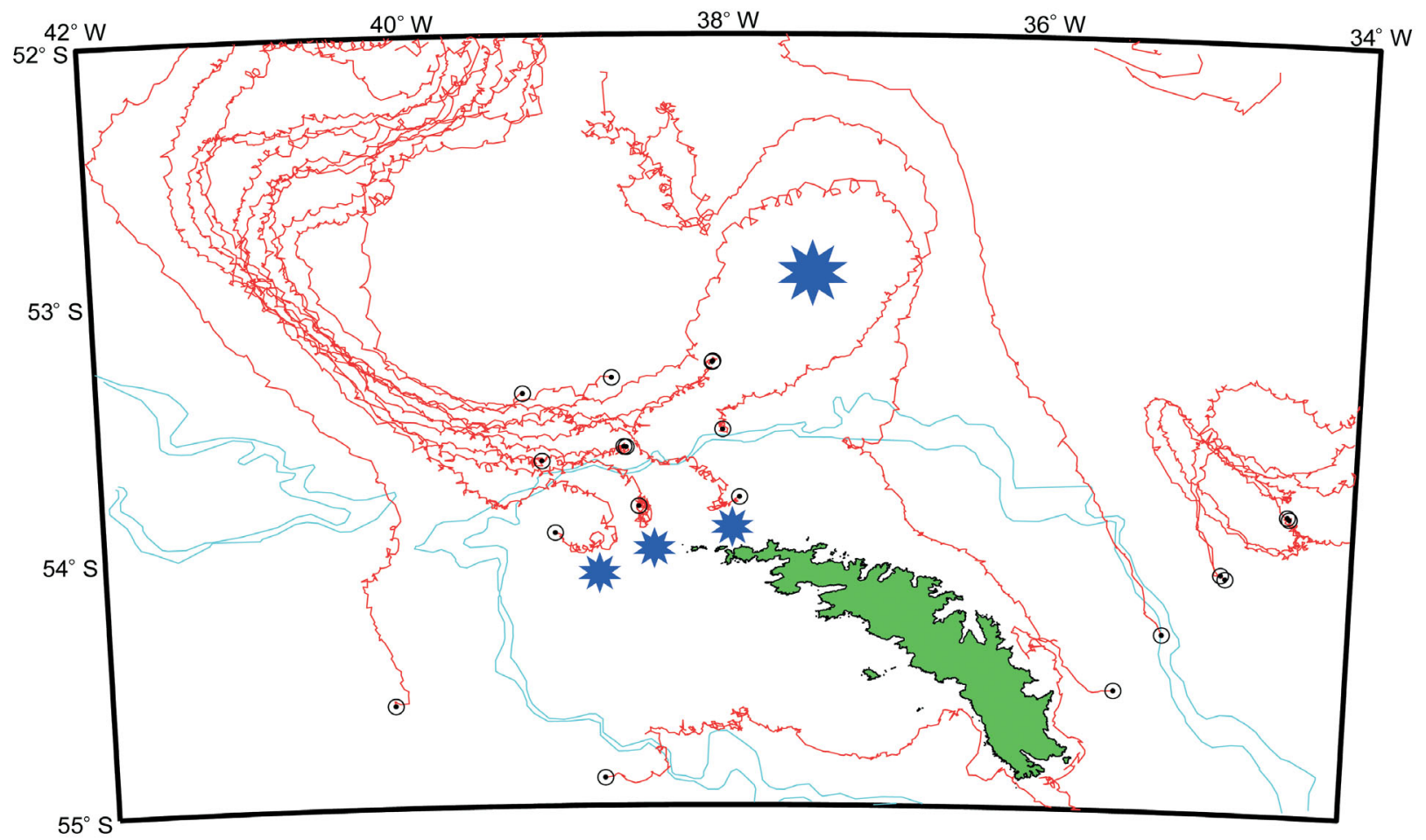

Fig. 6. ARGOS satellite telemetry drifting buoy data from Meredith et al. (2003). ๑: deployment locations; small blue stars: areas where the drifters were retained in mesoscale eddies; large blue star: area where drifters were steered by the flow over the steep bathymetry of the North Georgia Rise (Meredith et al. 2003 
gons fell along a single vector suggests that penguins used a very simple strategy for locating prey during this period of the breeding season. Thus, birds potentially headed along a given trajectory towards the shelf break until they encountered prey aggregations. Having found prey, they then fed until they either returned to the colony, or resumed the trajectory in search of further prey aggregations. This simple search strategy would potentially result in a greater swept volume per unit distance travelled over the ground, increasing the probability of finding food. The mean position of the colony foraging polygons potentially reflects the average distribution of prey found by the birds in any given year. Generally, most foraging activity occurred over the shelf, suggesting that in most years, birds found adequate prey aggregations before they reached the shelf break. However, in some years (1999 and 2004) most foraging activity occurred close to the shelf-edge, at approximately $53^{\circ} 35^{\prime} \mathrm{S}$ or $53.59^{\circ} \mathrm{S}$ (Table 3, Fig. 3). Analyses of the acoustic distribution of krill at South Georgia suggest that most biomass is located close to the shelf edge (Trathan et al. 2003). Thus, birds were travelling towards predictable prey aggregations, but may not have needed to travel all the way to the shelf break if they found adequate resources over the shelf.

\section{Colonies on islands}

Birds from Bird Island predominantly foraged to the north. These birds selected only a narrow range of foraging opportunities, heading towards the shelf break and the waters influenced by the sACCf. Over the $7 \mathrm{yr}$ that birds were tracked from Fairy Point, the principal trajectory was always towards the north, although there was some variability between years in the area used by birds (Table 3 ).

In contrast, birds from the Willis Islands generally headed south away from the sACCf, indicating that it was not necessarily the presence of this large-scale oceanographic feature that dictated their principal foraging locations. This would suggest that predictable aggregations of prey were also available in other areas; these areas may potentially be associated with smaller-scale physical features (bathymetric features or oceanographic features) that increase prey availability. One of the birds tracked from the Willis Islands followed a direction (north towards the waters influenced by the sACCf) that was diametrically opposite to that followed by all other birds. This was only possible because the coastline of the Willis Islands afforded this bird the opportunity to forage over a very wide range. Hence, it may be that birds use a number of preferred foraging areas, and their particular choice depends upon prevailing conditions and recent experience.

\section{Colonies on straight coastlines}

Birds from Rookery Bay foraged northwards, directly out from their colony. This was not unexpected given the narrow range of opportunities afforded to birds breeding at this location as the surrounding coastline limited any radial expansion in their foraging area. Birds tended to head towards, but not as far as, the shelf break, where the dominant oceanographic feature in the region (the sACCf) was located.

\section{Comparison between birds from closely adjacent colonies in the same year}

During the brood-guard period of 2003, birds from 3 closely adjacent colonies (Fairy Point, Goldcrest Point and Macaroni Cwm) on Bird Island were tracked (Table 2, Figs. 4 \& 5a). These showed very similar foraging trajectories, with birds foraging over the northern shelf area.

Birds from Fairy Point and Goldcrest Point in particular showed similar trajectories, with similar distances travelled and similar levels of sinuosity. Foraging trips from the 2 colonies were generally directional, indicated by the average sinuosity levels of between 1.1 and 1.7 (sinuosity levels of 1.0 result from a direct straight line trip, both out and then back over the same course). The mean positions for the 2 foraging polygons (average latitude and longitude, Table 3) were also very similar, as was the position of the main foraging effort. This is perhaps not surprising, given the very close proximity of these colonies to one another.

In contrast, birds from Macaroni Cwm showed a different foraging pattern, but again to the north of Bird Island. The overlap between the $90 \%$ polygons for Macaroni Cwm and Fairy Point (or Goldcrest Point) was very small, despite the very close proximity of all 3 colonies. One plausible explanation for this is that the onset of brood-guard at Macaroni Cwm was slightly later than at Fairy Point (or Goldcrest Point). Thus, it is feasible that different oceanographic conditions were present when the birds from Macaroni Cwm were tracked, and this could explain the difference in the foraging polygon. However, given the inter-annual consistency in the longitude of the maximum accumulated time spent foraging (Table 3) and the consistency in the overlap of polygons observed between years at Fairy Point (Table 4), it seems more probable that birds from Macaroni Cwm forage mainly in different areas to those used by birds from Fairy Point.

\section{Foraging towards oceanographic features}

Penguins from the 3 colonies at Bird Island (Fairy Point, Goldcrest Point and Macaroni Cwm) and from 
Rookery Bay foraged towards the flow of water at the shelf-edge where krill abundance has been shown to be generally higher (Trathan et al. 2003). Hence, the observed direction of foraging was across the shelf towards the waters influenced by the sACCf, in accordance with the simple foraging strategy suggested above. Over the shelf, the net westward flow of water is slower than at the shelf break and offshelf (Meredith et al. 2003) and is subject to a series of eddies which may be areas of retention for prey; evidence for such eddies is shown by the mesoscale retention patterns in the drifter trajectories, both to the north and west of Bird Island (Fig. 6, see also Meredith et al. 2003). These eddies are likely to be variable in space and time, but could potentially alter the effective density of the prey field for penguins as they swim out from their colonies. The westward flow of water to the south and north of South Georgia (Fig. 6) is aliased in the patterns of ocean colour recorded by satellite remote sensing (Korb \& Whitehouse 2004). Though levels of primary productivity are variable between years, the westward oceanographic flow dominates (Korb \& Whitehouse 2004) such that mesoscale variability is likely to affect the prey field in most years.

At the Willis Islands, birds did not forage towards the sACCf; instead they headed south (Fig. 5b) towards a flow of water flowing north-west across the shelf (Fig. 6, see also Korb \& Whitehouse 2004). Here, birds could be following the same simple foraging strategy described above. Certainly the foraging trips from this colony are consistent with this same pattern of behaviour.

\section{Inferences about the prey field}

Antarctic krill are a patchy resource, occurring in continuous layers, discrete swarms and as low density, loose aggregations (Miller \& Hampton 1985). Though krill are large zooplankton (or micro-nekton), they have only relatively limited control over their location (Marr 1963). Indeed, modelling studies have recently suggested that krill arrive at South Georgia with the flow of the ACC, with the sACCf potentially transporting much of the biomass (Hofmann et al. 1998, Murphy et al. 1998). If krill are arriving with the flow of the ACC, then layers, swarms and loose aggregations will flow past South Georgia and foraging penguins would most effectively search for them by swimming perpendicularly (Fig. 3) to the water flow along the shelf and shelf break (Fig. 6).

Alternatively, if krill biomass is produced in situ at South Georgia, as suggested by some authors (e.g. Nicol 2004), and only a relatively minor proportion of the biomass arrives with the flow of the ACC, then it may be anticipated that penguins would forage in random directions and not always in a vector across the main flow of the ACC. That penguins have such predictable foraging strategies, within and between years, affirms the importance of the ACC as a mechanism for transporting krill to South Georgia.

The foraging pressure associated with the various macaroni penguin colonies at South Georgia will vary and will also likely reflect the number of breeding pairs in the colony (cf. Ainley et al. 1995). Large breeding aggregations, such as occur on the Willis Islands, therefore, represent very large prey demands that must be predictable over varying temporal and spatial scales. That such large and predictable resources occur could be a consequence of the separate flows within the ACC that converge close to the western end of South Georgia. Waters of the southern ACC come close to South Georgia, indicated by the main flow of the sACCf to the north of the island (Orsi et al. 1995, Trathan et al. 1997, Thorpe et al. 2002). Similarly, more northern waters of the Antarctic Zone (lying between the sACCf and the Antarctic Polar Front) flow towards the western end of the island (Orsi et al. 1995, Trathan et al. 1997). The confluence of these flows occurs to the west of the Willis Islands (see also Fig. 6). This confluence potentially represents 2 sources of krill, as krill arrive in the flow of the ACC. These 2 streams may jointly represent a more predictable flux of krill and may help explain the presence of the larger breeding aggregations of macaroni penguins at the western end of South Georgia.

The standing stock of krill towards the western end of South Georgia is generally lower than at the eastern end (Trathan et al. 2003); however, the observable biomass of krill represents a balance between flux, standing stock, in situ production and consumption by predators. The higher levels of predator foraging pressure in the west consequent on a more predictable prey field may thus result in the lower observable biomass of krill.

Other smaller-scale physical features will also potentially affect the prey field at South Georgia and thus penguin foraging. For example, submarine banks and canyons are known to affect prey aggregations (Genin 2004) and thus potentially the location of penguin colonies where prey aggregations may be more predictable. Aggregations of zooplankton, micro-nekton and fish are frequently observed above seamounts, canyons and shelf breaks; these are produced by different mechanisms, all driven by ocean currents (Genin 2004).

\section{Population level resource demands}

Recent analyses of the macaroni penguin population at South Georgia have shown that numbers may have declined (Trathan et al. 1998, Trathan 2004). Study colonies at Bird Island, South Georgia decreased by 
almost $50 \%$ over the latter part of the twentieth century. The reasons for this decline are unknown, but are of sufficient concern that the species is now listed as 'vulnerable' (Hilton-Taylor 2000). Some authors have suggested that ecological regime shifts in the southwest Atlantic may have resulted in lower krill biomass with consequent declines in many predator populations (Reid \& Croxall 2001, Atkinson et al. 2004). However, others have suggested that the decline may be related to competitive exclusion by Antarctic fur seals Arctocephalus gazella (Barlow et al. 2002, Trathan \& Croxall 2004), populations of which have recovered in recent decades to levels that are now thought to be approaching their pre-sealing numbers (Boyd 1993). Antarctic fur seal breeding beaches predominantly occur at the north-western end of South Georgia, in areas occupied by macaroni penguins. Competition in these areas is therefore likely to be of ecological significance.

Our results have highlighted the ecological complexity of macaroni penguins foraging behaviour during the brood-guard period, and also how these penguins utilize their available seascape. Thus, though specific oceanographic features may be important, they are not the main focus of foraging trips during brood-guard. Evidence so far suggests that individual colonies have distinct foraging areas, separate from neighbouring colonies, though overlap is evident for very closely located colonies. Further, the penguins do not range evenly over the available area, but forage along a restricted set of bearings. Only with such long-term studies, allied with adequate environmental information (both physical and biological), will we be able to fully understand seabird foraging strategies.

\section{Behavioural aspects of foraging}

The direction that birds travelled when leaving the colony at Fairy Point was very consistent between years (Table 3 ). Various explanations exist as to how birds navigate, and not only when following a fixed trajectory. A number of bird species use cues such as magnetism (Sandberg et al. 2000), topographic features (including wind direction), the stars, the sun and odours (Wiltschko \& Wiltschko 1999a,b). Different species may use these cues in different orders of priority, and some cues may always be used in preference to others. Though the literature on bird navigation is extensive, the available data are currently inadequate to resolve how penguins navigate and further detailed experimental protocols are required to resolve this intriguing result.

Consequently, in addition to information on the environment, we also need to understand how birds sam- ple the environment and how they make decisions about their location, their energy budget and how they detect prey if we are to understand their foraging ecology and make predictions about the impacts of anthropogenic forcing and subsequent ecosystem response.

\section{CONCLUSIONS}

Our results clearly showed that birds do not radiate from their colony covering all the ocean area within a fixed foraging range; rather, their main foraging effort was directional and generally directly offshore from their colony. This leads to areas that are predominantly used by one colony with potentially some minor overlap between adjacent colonies. Thus, our results suggest that penguins concentrate their foraging effort in certain areas and that these differ between colonies, even those that are closely adjacent. In all situations, this would potentially lead to birds exploiting only a restricted part of their potential foraging range.

Acknowledgements. We thank the National Geographic Committee for Research and Exploration for funding the charter of the MV 'Golden Fleece', without which this study would not have been possible. We also thank J. Hall and M. Dinn from the British Antarctic Survey (BAS) Operations Group for their support, valuable advice and willing help. We also gratefully acknowledge the comments of 4 anonymous referees who helped us to greatly improve this manuscript with their insightful comments.

\section{LITERATURE CITED}

Ainley DG, Nur N, Woehler EJ (1995) Factors affecting the distribution and size of pygoscelid penguin colonies in the Antarctic. Auk 112:171-182

Atkinson A, Siegel V, Pakhomov E, Rothery P (2004) Longterm decline in krill stock and increase in salps within the Southern Ocean. Nature 432:100-103

Barlow KE, Croxall JP (2002) Seasonal and interannual variation in foraging range and habitat of macaroni penguins at South Georgia. Mar Ecol Prog Ser 232:291-304

Barlow KE, Boyd IL, Croxall JP, Reid K, Staniland IJ, Brierley AS (2002) Are penguins and seals in competition for Antarctic krill at South Georgia? Mar Biol 140:205-213

Boyd IL (1993) Pup production and distribution of breeding Antarctic fur seals (Arctocephalus gazella) at South Georgia. Antarct Sci 5:17-24

Boyd IL (2002) Estimating food consumption of marine predators, Antarctic fur seals and macaroni penguins. J Appl Ecol 39:103-119

Brown CR (1987) Travelling speed and foraging range of macaroni and rockhopper penguins at Marion Island. J Field Ornithol 58:118-125

Cherel Y, Tremblay Y, Guinard E, Georges JY (1999) Diving behaviour of female northern rockhopper penguins, Eudyptes chrysocome moseleyi, during the brooding period at Amsterdam Island (Southern Indian Ocean). Mar Biol 134:375-385 
Clark BD, Bemis W (1979) Kinematics of swimming of penguins at the Detroit Zoo. J Zool 188:411-428

Croxall JP, Prince PA (1987) Seabirds as predators on marine resources, especially krill, at South Georgia. In: Croxall JP (ed) Seabirds: feeding ecology and role in marine ecosystems. Cambridge University Press, Cambridge, p 347-368

Croxall JP, McCann TS, Prince PA, Rothery P (1988) Reproductive performance of seabirds and seals at South Georgia and Signy Island, South Orkney Islands 1976-1987; implications for Southern Ocean monitoring studies. In: Sahrhage D (ed) Antarctic Ocean and resources variability. Springer-Verlag, Berlin, p 261-285

Croxall JP, Briggs DR, Kato A, Naito Y, Watanuki Y, Williams TD (1993) Diving pattern and performance in the macaroni penguin Eudyptes chrysolophus. J Zool 230:31-47

de le Brooke M (2004) The food consumption of the world's seabirds. Proc R Soc Lond B (Suppl) 272:S246-248

Genin A (2004) Bio-physical coupling in the formation of zooplankton and fish aggregations over abrupt topographies. J Mar Syst 50:3-20

Green CJ, Trathan PN, Preston M (2006) A new automated logging gateway to study the demographics of macaroni penguins (Eudyptes chrysolophus) at Bird Island, South Georgia: testing the reliability of the system using radio telemetry. Polar Biol doi:10.1007/s00300-006-0143-4

Grémillet D, Dell'Omo G, Ryan PG, Peters G, Ropert-Coudert Y, Weeks SJ (2004) Offshore diplomacy, or how seabirds mitigate intra-specific competition: a case study based on GPS tracking of Cape gannets from neighbouring colonies. Mar Ecol Prog Ser 268:265-279

Hilton-Taylor C (2000) 2000 IUCN red list of threatened species. IUCN, Gland

Hofmann EE, Klinck JM, Locarnini RA, Fach B, Murphy EJ (1998) Krill transport in the Scotia Sea and environs. Antarct Sci 10:406-415

Jouventin P, Weimerskirch H (1990) Satellite tracking of wandering albatrosses. Nature 343:746-748

Korb RE, Whitehouse M (2004) Contrasting primary production regimes around South Georgia, Southern Ocean: large blooms versus high nutrient, low chlorophyll waters. Deep-Sea Res I 51:721-738

Marr JWS (1963) The natural history and geography of the Antarctic krill (Euphausia superba). Discovery Rep 32: 33-464

Meredith MP, Watkins JL, Murphy EJ, Cunningham NJ and 5 others (2003) An anticyclonic circulation above the Northwest Georgia Rise, Southern Ocean. Geophys Res Lett 30:Article 2061, OCE5-1-OCE5-5

Miller DGM, Hampton I (1989) Biology and ecology of the Antarctic krill. BIOMASS Sci Ser 9. SCAR, Cambridge

Mori Y, Boyd IL (2004) Segregation of foraging between 2 sympatric penguin species: Does rate maximisation make the difference? Mar Ecol Prog Ser 275:241-249

Murphy EJ, Watkins JL, Reid K, Trathan PN and 6 others (1998) Innterannual variability of the South Georgia marine ecosystem: biological and physical sources of variation in the abundance of krill. Fish Oceanogr 7:381-390

Murphy EJ, Watkins JL, Meredith MP, Ward P, Trathan PN, Thorpe SE (2004) Southern Antarctic Circumpolar Current Front to the northeast of South Georgia: horizontal advection of krill and its role in the ecosystem. J Geophys Res 109:C1:Art No C01029

Nicol S (2004) Living krill, zooplankton and experimental investigations: a discourse on the role of krill and their experimental study in marine ecology. Mar Freshw Behav Physiol 36:191-205

Orsi AH, Whitworth T, Nowlin WD (1995) On the meridional extent and fronts of the Antarctic Circumpolar Current. Deep-Sea Res I 42:641-673

Reid K, Croxall JP (2001) Environmental response of upper trophic-level predators reveals a system change in an Antarctic marine ecosystem. Proc R Soc Lond Ser B Biol Sci 268:377-384

Ryan PG, Petersen SL, Peters G, Grémillet D (2004) GPS tracking a marine predator: the effects of precision, resolution and sampling rate on foraging tracks of African penguins. Mar Biol 145:215-223

Sandberg R, Backman J, Moore FR, Lohmus M (2000) Magnetic information calibrates celestial cues during migration. Anim Behav 60:453-462

Thorpe SE, Heywood KJ, Brandon MA, Stevens DP (2002) Variability of the southern Antarctic Circumpolar Current front north of South Georgia. J Mar Syst 37:87-105

Trathan PN (2004) Image analysis of color aerial photography to estimate penguin population size. Wildl Soc Bull 32:332-343

Trathan PN, Croxall JP (2004) Marine predators at South Georgia: an overview of recent bio-logging studies. Mem Natl Inst Polar Res 58:120-134

Trathan PN, Brandon MA, Murphy EJ (1997) Characterisation of the Antarctic Polar Frontal Zone to the north of South Georgia in summer 1994. J Geophys Res 102:C5 10483-10497

Trathan PN, Murphy EJ, Croxall JP, Everson I (1998) Use of at-sea distribution data to derive potential foraging ranges of macaroni penguins during the breeding season. Mar Ecol Prog Ser 169:263-275

Trathan PN, Brandon MA, Murphy EJ, Thorpe SE (2000) Transport and structure within the Antarctic Circumpolar Current to the north of South Georgia. Geophys Res Lett 27:1727-1730

Trathan PN, Brierley AS, Brandon MA, Bone DG, Goss C, Grant SA, Murphy EJ, Watkins JL (2003) Oceanographic variability and changes in Antarctic krill (Euphausia superba) abundance at South Georgia. Fish Oceanogr 12: 569-583

Wanless S, Corfield T, Harris MP, Buckland ST, Morris JA (1993) Diving behavior of the shag Phalacrocorax aristotelis (Aves, Pelecaniformes) in relation to water depth and prey size. J Zool 231:11-25

Williams TD (1995) The penguins. Oxford University Press, Oxford

Williams TD, Croxall JP (1991) Annual variation in breeding biology of macaroni penguins, Eudyptes chrysolophus, at Bird Island, South Georgia. J Zool 223:189-202

Wilson RP, Pütz K, Peters G, Culik B, Scolaro JA, Charrassin JB, Ropert-Coudert Y (1997) Long-term attachment of transmitting and recording devices to penguins and other seabirds. Wildl Soc Bull 25:101-106

Wilson RP, Grémillet D, Syder J, Kierspel MAM and 7 others (2002) Remote-sensing systems and seabirds: their use, abuse and potential for measuring marine environmental variables. Mar Ecol Prog Ser 228:241-261

Wiltschko R, Wiltschko W (1999a) The orientation system of birds - I. Compass mechanisms. J Ornithol 140:1-40

Wiltschko R, Wiltschko W (1999b) The orientation system of birds - II. Homing and navigation. J Ornithol 140: 129-164

Submitted: July 27, 2005; Accepted: March 9, 2006

Proofs received from author(s): August 14, 2006
Editorial responsibility: Rory P. Wilson (Contributing Editor), Swansea, UK 